\title{
What Is Relationship between Profits and Dividends in Agricultural Legal Entities?
}

\author{
Renáta Krajčírová ${ }^{1}$, Alexandra Ferenczi Vaňová1, Michal Munk² \\ ${ }^{1}$ Department of Accounting, Faculty of Economics and Management, Slovak University of Agriculture, \\ Nitra, Slovakia \\ ${ }^{2}$ Department of Informatics, Faculty of Natural Sciences, Constantine the Philosopher University in Nitra, \\ Slovakia
}

\begin{abstract}
The paper assesses the development of profits in the selected legal entities of agricultural primary production in the Slovak Republic as well as the progress in taxation of profit distribution in the form of dividends including mutual correlations in 2009-2014. Mean values of profit or loss are noted for the diverse development of examined variables. The development of mean values of dividends from the net profit is achieved a slight increase in the selected years. The dividends generated in the analysed periods were not taxable because according to the Slovak tax law dividends were not subject to tax. The results of testing of differences significance in profit or loss values in the reviewed commercial companies and cooperatives determined that the statistically significant differences existed in the particular years. In case of dividends no statistically significant differences were found. The statistically significant correlations between profit and dividends were reported by means of nonparametric correlation analysis except for the profit generated in the year 2009 and dividends in the year 2010 .
\end{abstract}

\section{Keywords}

Profit, shareholder, profit distribution, dividends, agricultural legal entity, income tax, withholding tax.

Krajčírová, R., Ferenzi Vaňová, A. and Munk, M. (2019) "What Is Relationship between Profits and Dividends in Agricultural Legal Entities?", AGRIS on-line Papers in Economics and Informatics, Vol. 11, No. 1, pp. 55-64. ISSN 1804-1930. DOI 10.7160/aol.2019.110106.

\section{Introduction}

Profit after income tax which a legal entity achieved in a prior accounting period is obliged to be settled within the subsequent accounting period. The shareholder's/cooperative member's right for profit share belongs to his basic rights and results from the ownership share in a legal entity's share capital. If Articles of Association do not determine the manner and amount to be paid as a profit share, it is applied that the profit is divided in accordance with their shares of unpaid contribution. The legal entity can allocate profit shares only from the net profit (i) decreased by shares in the reserve fund, (ii) increased by retained earnings and funds created from profit. In general, if a legal entity does not disclose the profit it cannot allocate shares in profit to a shareholder in the form of dividends. Despite that fact the allocation of dividends is not a legal right; it is the subject to a collective approval of statutory body deciding about the profit distribution between shareholders/members of cooperative.
The accounting result (profit or loss) is an important financial indicator expressing the effectiveness and efficiency of business activities mainly in connection to the contributed capital. It is the basic information source and the measurement of financial profitability of contributed capital to the respective accounting period (Baštincová, 2007). The Act on Accounting (2018) defines the profit or loss as the monetary final result of the company's activities achieved during the accounting period. Pursuant the accounting legislation of the Slovak Republic profit or loss is calculated in the appropriated structure in the income statement included in the individual financial statements. The individual financial statements provide basic information source to a company management but as well as to the external users of information (Košovská and Váryová, 2015). According to Hornungová and Milichovský (2016), the income statement representing the influence of managerial operational decisions on the economic results of the company, 
has been used to study company performance (in this case the information whether the company generates profit or loss). Tumpach et al. (2014) states there are different groups of external users of business information for the financial statements whose needs are more often in the mutual contradiction. As a result, data about the business transactions, events and conditions need to be presented in the form of general purpose financial statements. The issue of accounting information provided by the company financial reporting is treated by Saxunová (2014). By means of the specific function and the importance of agriculture within the national economy this sector is the subject of government regulations which deforms a market and market prices as these are the input for accounting systems of agricultural companies and significantly influence the accounting result of agricultural companies and the assessment of their economic performance (Dvořáková, 2012). Hanová et al. (2015) compared economic position of the Slovak Republic with the EU countries by using the selected socio-economic indicators. The participation in profit (loss) belongs to criteria according to which the legal form is opted. The selection of a business legal form belongs to long-term effective decisions and it presents the factor substantially influencing the financial politics of a business (Sivák et al., 2015). The legislation stipulates mainly the manner of payments, respectively shares in profits in relation to the profit distribution (Commercial Code, 2018). Profit distribution and loss settlement is decided by the General Meeting of a company, generally when the financial statements are approved. Particular profit distribution depends on the balances of equity, internal directives of an accounting entity and presents in the Articles of Incorporation or Articles of Association, on the amount of profit or loss and other circumstances (Šteker and Otrusinová, 2013). In many countries the corporate profit is subject by two level of tax, corporate level of income tax and investor level tax when the corporate net profit is distributed as dividends. The mechanism of dividend payments differentiates according to individual countries (Král'ovič and Vlachynský, 2002). The issue of profit distribution policy is a topic often discussed by many authors in various jurisdictions such as Široký and Valentová (2013), Sander et al. (2014), MatuszewskaPierzynka (2015), Mei and Wei (2015), Toder and Viard (2016). The investors shift the profit to low tax jurisdictions and the concern grows due to increasing international tax rate differentials
(Martini et al., 2012).

The aim of the paper is to assess development and mutual relationship between profit and its distribution in the form of dividends as well as to consider the legal treatment of dividends taxation in the selected legal entities of agricultural primary production in the Slovak Republic (hereinafter referred to as "SR" or the "Slovak Republic") by means of testing of differences significance and correlations of reviewed variables in the analysed period of the years 2009-2014.

\section{Materials and methods}

Data source for the assessed legal entities is presented by the Information Letters of the Ministry of Agriculture and Rural Development of the Slovak Republic (hereinafter referred to as "MARD SR"). These are the data from individual financial statements of agricultural legal entities (limited liability companies, joint stock companies and agricultural cooperatives).

The taxation of profit and its distribution in the form of dividends within the territory of the Slovak Republic is considered in accordance with the provisions of the Act no. 595/2003 Coll. on Income Tax as amended (further referred as "Income Tax Act") as well as from the international perspective, in particular, the provisions of the Council Directive 2011/96/EU of 30 November 2011 on the common system of taxation applicable in the case of parent companies and subsidiaries of different member states (further referred as "EU Parent Subsidiary Directive" or "Directive") is also taken into account.

The significant differences and correlations in values of dependent variables are examined, namely Profit and Dividends for the years 20092014. The selected descriptive characteristics are calculated for the assessed variables - the point and interval mean estimate, the standard error of mean estimate and the standard deviation.

The analysis of variance and repeated measures (ANOVA Repeated Measures) is the most suitable analysis for the testing of differences significance of dependent variables.

The analysis model of variance with repeated measures without division to groups:

$Y_{i j}=\mu+\alpha_{j}+\beta_{i}+\lambda_{i j}+e_{i j}$

Where $\mu$ is an average of dependent variable, $\alpha_{j}$ is effect of $j$ repeated measure, $\beta_{i}$ is effect of $i$ object, $\lambda_{i j}$ is an interaction between the repeated measure $j$ 
and the object $i$.

We are interested in one zero hypothesis:

$\mathrm{H} 0_{\mathrm{A}}: \mu_{1}=\ldots=\mu_{I}$ (averages of repeated measures are the same).

The restricted condition of using the significance tests is the condition of sphericity of the covariance matrix - the equality of variance and covariance in the covariance matrix for repeated measures. Mauchley Sphericity Test is used for the verification of the covariance matrix sphericity - the assumption of using the analysis of variance for repeated measures with more than two levels. If the condition of covariance matrix sphericity is not met, the amount of the first level error is increasing. In such cases the degrees of freedom of used F-test are adjusted by means of Greenhouse/Geisser and Huynh/Feldt Adjustments. In order to determine the statistically significant differences at the level of intragroup factor Year the multiple comparison is used, namely Tukey HSD Test. The null hypothesis assumes that in the profit or loss there are no statistically significant differences between the assessed years. The null hypothesis assumes that there are no statistically significant differences in paid dividends from profit between the assessed years. It means that the variables Profit and Dividends are not dependent on the intragroup factor Year.

The nonparametric correlation - Spearman Rank Order Correlations is used for the assessment of correlation significance between selected variables during the analysed years due to the deviations from the normality. The null hypothesis states that examined variables are independent (Munk, 2011).

MS Access, MS Excel and the system STATISTICA are used for the data processing from database and the analysis of relations between selected variables.

\section{Results and discussions}

In general, profit presents generated result in the accounting period which positively influences the equity of a legal entity. Profit or loss disclosed by a legal entity achieved for a current accounting period shall be settled till the end of the following accounting period. Based on the decision of the statutory body of a commercial company or cooperative the profit part can be allocated in the dividends in the favour of shareholders/cooperative members who participate in the equity of a legal entity.

The calculation of selected descriptive characteristics and 95\% interval of mean reliability presents the results for the analysed variables of the selected legal entities of agricultural primary production in the Slovak Republic in the years 2009-2014.

Results from accounting of legal entities figured the differentiated development in the analysed years (Figure 1) based on the achieved values of the development of mean level of profit or loss in the selected agricultural legal entities. In the year 2013 the interval mean estimate of profit or loss was at the level -29890.5 EUR till 1014.2 EUR.

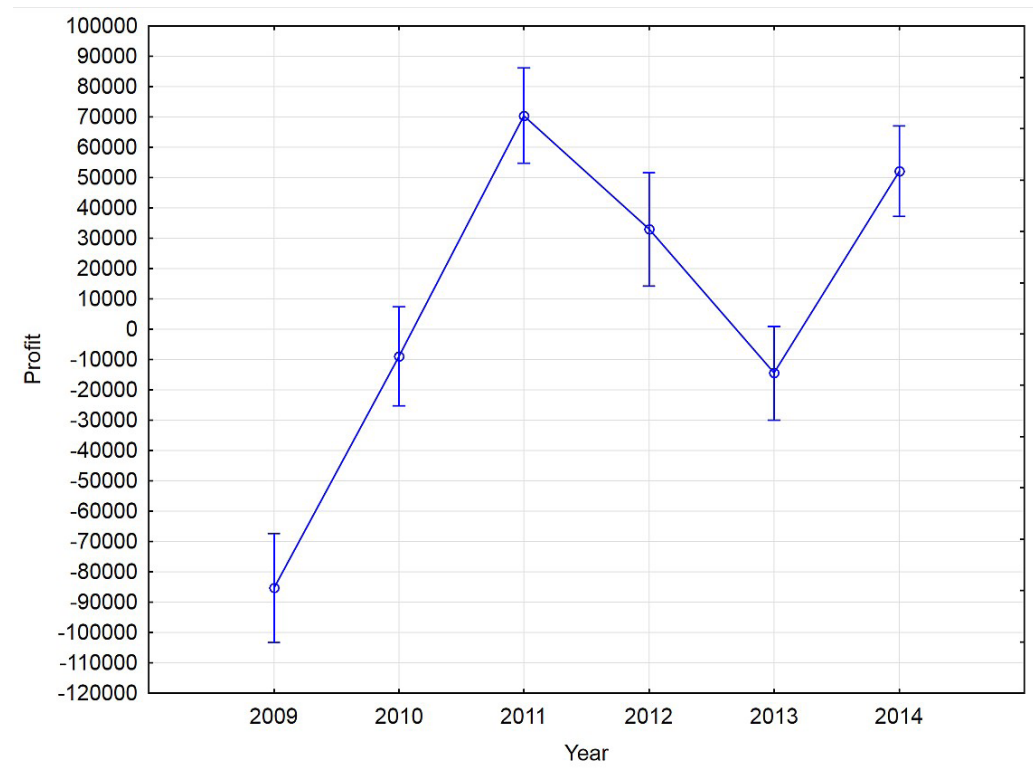

Source: Own calculation based on data from the Information Letters of the MARD SR

Figure 1: Means plot for variables Profit 2009-2014. 
For comparison in the year 2012 the mean amount of profit was at the level 32970.2 EUR and in the year 2014 at the level 52165.0 EUR. The highest average level of profit was recorded in the year 2011, on the contrary the highest average value of loss was in the year 2009.

The significance of differences at the level of factor Year was tested in connection with the presented results of selected descriptive characteristics of examined variables.

Based on the results of Mauchley Sphericity Test $(W=0.582 ;$ Chi-square $=532.706 ; d f=14$; $p=0.0000)$ the assumption of using the analysis of variance for repeated measures was breached in case of the variable Profit.

Because of the sphericity assumption breach the adjusted tests of significance Adjusted Univariate Tests for Repeated Measure (Table 1) were used for the testing of differences. In case of the dependent variable profit the null hypothesis was set which at the level of factor Year assumes that there are no statistically significant differences between the analysed years in the obtained profit or loss. The hypothesis was rejected with $99.9 \%$ reliability.

If the null hypothesis was rejected which states that there are no statistically significant differences between the analysed years, Tukey HSD Test (Table 2) is applied, on the basis of which there are statistically significant differences in the individual years of the recognized profit after tax for the period.

Based on the multiple comparison we identified three homogeneous groups (2013, 2010),
(2012, 2014), (2014, 2011), it means that in such cases the statistically significant differences were not demonstrated between the analysed years.

As regards the obtained results of selected descriptive characteristics it can be stated that in the reviewed period of years 2009-2014 the slightly increasing trend was determined in the mean amount of dividends in the selected agricultural legal entities in the Slovak Republic (Figure 2) while the development of such a variable influence mainly the recognized accounting result obtained in the prior accounting period. The most significant increase in dividends was achieved in the year 2013 when the highest mean amount of dividends from profit distribution recognized in the accounting period 2012 was disclosed at the level 117319.6 EUR. In the year 2014, the interval mean estimate of dividends was at level 83361.3 EUR till 132530.6 EUR.

As well as in the case of profit, the validity assumption was breached even for the dependent variable which was the level of dividends based on the results of the Mauchley Sphericity Test $(W=0.129 ;$ Chi-square $=1.092 .001 ; d f=14$; $p=0.0000)$.

Adjusted Univariate Tests for Repeated Measure (Table 3) were used for the testing of differences significance. The null hypothesis was set also for the assessed variable dividends which assumes that there are no statistically significant differences between the amounts of dividends from profit between the reported years.

At the level of factor Year no statistically significant difference is determined in the variable Dividends

\begin{tabular}{|c|c|c|c|c|c|c|c|c|}
\hline & $\begin{array}{c}\text { G-G } \\
\text { Epsilon }\end{array}$ & $\begin{array}{c}\text { G-G } \\
\text { df1 }\end{array}$ & $\begin{array}{c}\text { G-G } \\
\text { df2 }\end{array}$ & $\begin{array}{c}\text { G-G } \\
\text { p }\end{array}$ & $\begin{array}{c}\text { H-F } \\
\text { Epsilon }\end{array}$ & $\begin{array}{c}\text { H-F } \\
\text { df1 }\end{array}$ & $\begin{array}{c}\text { H-F } \\
\text { df2 }\end{array}$ & $\begin{array}{c}\text { H-F } \\
\text { p }\end{array}$ \\
\hline Year & 0.817 & 4.084 & 4027.256 & 0 & 0.821 & 4.104 & 4046.101 & 0 \\
\hline
\end{tabular}

Source: Own calculation based on data from the Information Letters of the MARD SR

Table 1: Adjusted Univariate Tests for variables Profit 2009-2014.

\begin{tabular}{|c|c|c|c|c|c|}
\hline Profit & Mean & $\mathbf{1}$ & $\mathbf{2}$ & $\mathbf{3}$ & $\mathbf{4}$ \\
\hline 2009 & -85268.4 & & & & $* * * *$ \\
\hline 2013 & -14438.2 & $* * * *$ & & & \\
\hline 2010 & -8916.5 & $* * * *$ & & & \\
\hline 2012 & 32970.2 & & $* * * *$ & & \\
\hline 2014 & 52165.0 & & $* * * *$ & $* * * *$ & \\
\hline 2011 & 70466.4 & & & $* * * *$ & \\
\hline
\end{tabular}

Source: Own calculation based on data from the Information Letters of the MARD SR

Table 2: Multiple comparison for variables Profit 2009-2014. 


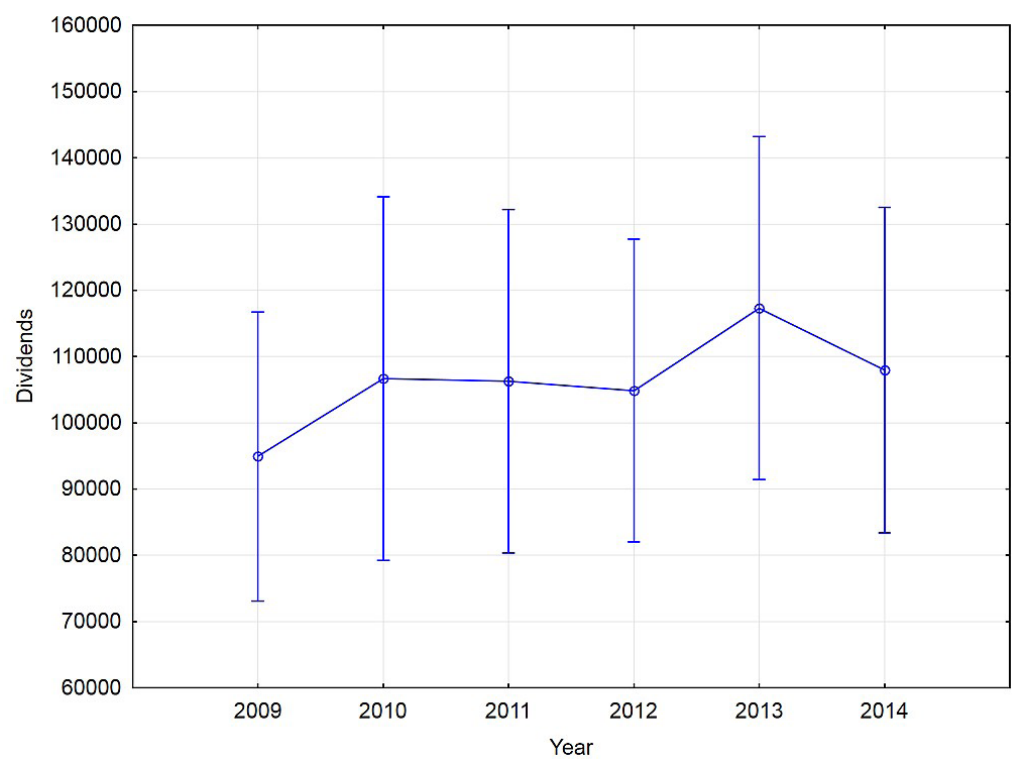

Source: Own calculation based on data from the Information Letters of the MARD SR

Figure 2: Means plot for variables Dividends 2009-2014.

\begin{tabular}{|c|c|c|c|c|c|c|c|c|}
\hline & $\begin{array}{c}\text { G-G } \\
\text { Epsilon }\end{array}$ & $\begin{array}{c}\text { G-G } \\
\text { df1 }\end{array}$ & $\begin{array}{c}\text { G-G } \\
\text { df2 }\end{array}$ & $\begin{array}{c}\text { G-G } \\
\text { p }\end{array}$ & $\begin{array}{c}\text { H-F } \\
\text { Epsilon }\end{array}$ & $\begin{array}{c}\text { H-F } \\
\text { df1 }\end{array}$ & $\begin{array}{c}\text { H-F } \\
\text { df2 }\end{array}$ & $\begin{array}{c}\text { H-F } \\
\text { p }\end{array}$ \\
\hline Year & 0.535 & 2.674 & 1433.527 & 0.2445 & 0.538 & 2.689 & 1441.393 & 0.2444 \\
\hline
\end{tabular}

Source: Own calculation based on data from the Information Letters of the MARD SR

Table 3: Adjusted Univariate Tests for variables Dividends 2009-2014.

\begin{tabular}{|l|c|c|c|c|}
\hline & Valid N & Spearman R & t(N-2) & p \\
\hline Dividends 2010 \& Profit 2009 & 854 & 0.066 & 1.924 & 0.0547 \\
\hline
\end{tabular}

Source: Own calculation based on data from the Information Letters of the MARD SR

Table 4: Nonparametric correlations for variables Profit 2009 and Dividends 2010.

\begin{tabular}{|l|c|c|c|c|}
\hline & Valid N & Spearman R & t(N-2) & p \\
\hline Dividends 2014 \& Profit 2013 & 826 & 0.104 & 3.012 & 0.0027 \\
\hline
\end{tabular}

Source: Own calculation based on data from the Information Letters of the MARD SR

Table 5: Nonparametric correlations for variables Profit 20013 and Dividends 2014.

( $p>0.05)$ and the null hypothesis is rejected. It means that there were no statistically significant differences in paid dividends between the particular years.

In connection with the before mentioned facts the nonparametric correlation analysis, specifically Spearman Rank Order Correlations, was used for the determination of significance level of correlations between the selected variables.

The statistically significant correlation between profit and dividends was determined within the analysed variables in the assessed commercial companies and cooperatives in the years 2009-2014, except for the profit recognized in the year 2009 and the dividends in the year 2010 (Table 4), the statistically insignificant trivial correlation was determined between the variables $(\mathrm{p}>0.05)$.

In the following analysed years the small statistically significant correlation was determined between the variables profit in the year 2010 and subsequently the dividends in the year 2011 $(p=0.0017)$, the profit in the year 2011 and the dividends in the year $2012(p=0.0037)$, the profit in the year 2012 and the dividends in the year $2013(\mathrm{p}=0.0000)$, as well as the profit in the year 2013 and the dividends in the year 2014 (Table 5).

The net profit after income tax for the accounting period influences not only the subject of selected business activities but as well as the legal form of entrepreneurship. The most frequently 
represented forms of legal entities of agricultural primary production in the Slovak Republic present limited liability companies, joint stock companies and cooperatives. Above mentioned issues are approved by Adamišin and Kotulič (2013) as commercial companies and agricultural cooperatives have a dominant position from legal entities and also have higher equity (Tóth et al., 2014).

Agricultural companies are influenced by the biological character of production, seasonality but as well as currently valid system of subsidies payments (Serenčéš et al., 2014). Biological nature of primary agricultural production significantly impact on the economic performance of legal entities (Gyurián and Kútna, 2015). According to Tóth et al. (2016) climate and weather related risks have a strong effect on agricultural production. Risk and return are negatively related and investors are comparing the risk with a profitability. With the entry of the Slovak Republic into the European Union (hereinafter referred to as "EU") companies can apply for assistance in the form of subsidies, grants or other assistance in the form of contributions from the funds of the SR or the EU. Despite the supports of SR or EU, companies need to reassess their economic activities and use of selected methods appropriately and prevent possible financial bankruptcy (Fil’arská, 2017). The entrance of the SR in the EU meant for the Slovak agricultural legal entities the possibility to adopt the financial compensations and the reduction of losses occurred by the influence of external effects under certain assumptions. The success of performed business activities is also the comparison of recognized profit or loss of legal entities with the achieved profit or loss of other companies in the agricultural primary production in the Slovak Republic. In the year 2009 despite of rising subsidies from the EU the unfavourable profit or loss of agricultural legal entities was caused mainly by low prices of agricultural produce (Report on agriculture and food sector in the Slovak Republic for the year 2009). In the year 2010 the profit or loss was influenced by various factors, except for the subsidies politics specifically direct payments, the faster increase in realization prices of agricultural produce as well as the input prices to agriculture and the flood impacts during the year caused the produce breakdown (Report on agriculture and food sector in the Slovak Republic for the year 2010). In the year 2013 the differences persisted in the profit or loss between companies in the various climatic conditions and in the legal forms. The subsidies were provided in accordance with the same criteria and conditions for both legal forms (Report on agriculture and food sector in the Slovak Republic for the year 2013).

Above mentioned statements are approved by the achieved results of selected descriptive characteristics regarding the development of profit or loss in the analysed commercial companies and cooperatives (Figure 1). In the years 2009, 2010 and 2013 the agriculture in the Slovak Republic as a whole obtained the negative accounting result (loss). On the contrary, in the years 2011, 2012 and 2014 the profit has been generated in the selected legal entities. The profit for a particular financial year after corporate income tax presents the net profit which can be allocated in the form of dividends between shareholders/ members of cooperative based on the decision of statutory body.

The profit of the Slovak legal entities is included in the general tax base. Corporate income tax in the SR is levied on all taxable income which is subject to standard corporate income tax rate. Income is computed as taxable revenues reduced by eligible costs incurred to generate, assure or maintain taxable income, subject to additional tax adjustments. From the international perspective, corporate income tax has been characterized in recent years by a gradual decrease of the nominal tax rate and the countries of the EU are no exception (Delgado et al., 2014). The corporate income tax has developed also in the Slovak Republic. Since 1993 the Slovak corporate income tax rate has fallen from $45 \%$ to $21 \%$. In comparison with the countries of Visegrad group, the corporate income tax burden is the highest in the Slovak Republic. Within the period of last 17 years, the most significantly reduced the corporate income tax rate in the Czech Republic, by 12 percentage points, i.e. the current corporate income tax rate amounts $19 \%$. The lowest corporate income tax rate presents Hungary in the amount of $9 \%$ (Taxation Trends in the European Union, 2018 Edition).

From the results of the selected descriptive characteristics it can be further stated that in the analysed period of the years 2009-2014 the slight increase of average value of dividends was determined in the agricultural commercial companies (Figure 2). This issue relates to the principle of a particular direct taxation. Pursuant to this principle the income shall not be the subject to income tax which has already been taxed. Before stated principle is the part of adopted tax reform approved in the Conception of tax reform in the years 2004-2006 and subsequently in the tax law (Act on Income Tax, 2017). 
In the Slovak Republic, the dividends paid out of profit earned in the analysed periods 2009-2014 were exempt from taxation, unless they were distributed out of profits earned prior to 1 January 2004. In this respect, it should be noted that, according to the amendment of the Income Tax Act, effective from 1 January 2017, dividends are subject to withholding tax (Act on Income Tax, 2018).

In particular, dividends are subject to tax if paid to individuals and, in specific cases, to companies for tax periods starting after 1 January 2017. Dividends paid to individual shareholders/ members of cooperatives or tax non-residents from contractual countries by Slovak legal entities are subject to withholding tax at a rate of $7 \%$, if the applicable double tax avoidance treaty does not determine otherwise. A withholding tax of $35 \%$ applies to dividends paid by Slovak entities to all tax residents from non-treaty countries (i.e. countries with which the Slovak Republic has not concluded a double tax avoidance treaty or a treaty on the exchange of tax information), including individuals and legal entities. The withholding tax shall be remitted to the tax authorities by the person paying the dividends within 15 days of the following month for the previous calendar month. The Slovak legal entity paying the dividends is obliged to report the withholding tax to the respective tax authorities. The same approach applies to dividends received by Slovak tax residents from foreign sources due to its shares in a foreign company from profit generated after 1 January 2017. In such case, those are included in the separate tax base and taxed at a rate of $7 \%$, or $35 \%$ in the case of receipt of dividends from non-contractual countries.

The EU Parent Subsidiary Directive is incorporated into the Slovak tax legislation and therefore need to be taken into consideration in respect of profit distribution. The Directive eliminates double taxation of profits distributed by a company resident in one EU member state to a parent company resident in another member state, affects the levying of withholding tax on dividends at domestic or tax treaty rates. The EU Parent Subsidiary Directive is mandatory for all EU member states, due to the fact that double non taxation is one of the key EU areas for urgent and coordinated action, it forms part of an on-going effort to improving the paper functioning of the internal market, by closing tax loopholes generated by exploiting the differences in national tax systems (Explanatory memorandum of the proposal for a Council Directive amending Directive 2011/96/EU on the common system of taxation applicable in the case of parent companies and subsidiaries of different Member States).

Should conditions stated in the EU Parent Subsidiary Directive are not met, the respective bilateral double tax avoidance treaty, as the important toll for elimination of double taxation of dividends, need to be considered. Currently, the Slovak Republic has an extensive array of double tax treaties, which normally reduced the withholding tax on dividends. The Double Tax Avoidance Treaty concluded with the Czech Republic reduces the withholding tax on dividends to $5 \%$ or $15 \%$. The reduced rate of $5 \%$ is applicable to legal entities directly holding a minimum stake of $25 \%$. The same rates on dividends are applied under the Double Tax Avoidance Treaty concluded with Hungary. The Double Tax Avoidance Treaty concluded between the Slovak Republic and Poland reduces the withholding tax on dividends in the amount of $0 \%$ or $5 \%$, while $0 \%$ is applicable to legal entities directly holding a minimum stake of $10 \%$ for a period of at least of 24 months as at the date of payment.

Based on the achieved results, statistically significant correlation was determined between profit and dividends in the assessed commercial companies and cooperatives within the reviewed variables. Whereas the right to the payment of particular dividends does not arise directly with the fact that a legal entity has obtained the profit in a financial year but it arises with the decision of a legal entity's statutory body about the distribution of profit between shareholders/members of cooperative.

\section{Conclusion}

The following conclusions are formulated based on the assessment of achieved profit or loss and paid out dividends as well as the assessment of their mutual correlations in the reviewed legal entities of agricultural primary production in the Slovak Republic in the analysed years 20092014. Based on selected descriptive characteristics the development of mean levels of profit or loss determined a differentiated progress in the particular period 2009-2014. On the contrary the mean value of dividends slightly increased in the analysed years. The facts related to the development of profit or loss in the agriculture are approved as well as by reports on agriculture and food sector in the Slovak Republic for the assessed years. The testing of differences significance in values of selected dependent 
variables (Profit and Dividends) which were treated on the base of independent variable at the level of factor Year resulted in the fact that between the analysed years there were determined the statistically significant differences in the achieved accounting results which were dependent on the reported years in which the assessment was conducted. The profit or loss in the commercial legal entity of agricultural primary production is affected by specific circumstances, namely climatic conditions, seasonality and adopted subsidies of non-investment character which cause the recognition of diverse levels of obtained profit or loss in the respective years. The statistically significant differences were not determined between the amounts of paid dividends between the analysed years, i.e. the dividends were not dependent on the concrete years. Before stated is approved by the fact that if a shareholder/member of cooperative does not decide on the distribution of net profit, it is not paid and is accumulated in the equity of a legal entity in the form of retained earnings. The statistically significant correlation between profit and dividends was recognized in the analysed years based on the determination of correlation significance between the reviewed variables in the selected commercial companies and cooperatives. The amount of dividends paid from profit depends on the decision of statutory body of a commercial company or cooperative as well as the amount of profit recognized in the prior accounting period. Pursuant to the concluded analysis it can be stated that if a legal entity does not recognize the profit, the share in profit in the form of dividends cannot be paid to shareholder/member of cooperative. The statutory body of a legal entity is obliged to decide about the dividends allocation. In the Slovak Republic, dividends were not taxable, unless they were distributed out of profits earned prior to 1 January 2004. Dividends distributed out of profits generated after 2017 and paid to resident individuals or tax non-residents from contractual countries by Slovak legal entities are subject to tax at a rate of $7 \%$ or $35 \%$. The foreign investors within the EU countries can benefit from the provisions of the EU Parent Subsidiary Directive which allows exempt dividends and other profit distribution paid by subsidiary companies to their parent companies from withholding taxes and eliminates double taxation. The additional tool for elimination of double taxation of dividends presents bilateral double tax treaties which the Slovak Republic has concluded. The provisions of double tax treaties in many cases also reduce withholding tax rate applicable on dividends in accordance with the national law.

\section{Acknowledgements}

The paper was supported by the project VEGA no. 1/0666/17 "Impact of Integration and Globalization on Business Risk in Slovak Agriculture".

\section{Corresponding authors}

Ing. Renáta Krajčirová, PhD.

Department of Accounting, Faculty of Economics and Management

Slovak University of Agriculture, Tr. Andreja Hlinku 2, 94976 Nitra, Slovakia

Email: renata.krajcirova@uniag.sk

\section{References}

[1] Act No. 431/2002 Coll. on Accounting as amended.

[2] Act No. 513/1992 Coll. Commercial Code as amended.

[3] Act No. 595/2003 Coll. on Income Tax as amended.

[4] Adamišin, P. and Kotulič, R. (2013) "Evaluation of the agrarian businesses results according to their legal form”, Agricultural Economics, Vol. 59, No. 9, pp. 396-402. ISSN 0139-570X.

[5] Baštincová, A. (2007) “Výsledok hospodárenia z účtovného a daňového hl'adiska”, Bratislava, Iura Edition, p. 102, ISBN 978-80-8078-144-6. (In Slovak)

[6] Council Directive 2011/96/EU of 30 November 2011 on the common system of taxation applicable in the case of parent companies and subsidiaries of different Member States (recast) (2011) [Online]. Available: https://eur-lex.europa.eu/legal-content/EN/TXT/ [Accessed: 14.07.2018]. 
[7] Delgado, F. J., Fernandez-Rodriguez, E. and Martinez-Arias, A. (2014) "Effective Tax Rates in Corporate Taxation: a Quantile Regression for the EU", Inžineriné Ekonomika-Engineering Economics, Vol. 25, No. 5, pp. 487-496. ISSN 1392-2785. DOI 10.5755/j01.ee.25.5.4531.

[8] Dvořáková, D. (2012) “Specifika účetnictví a oceňování v zemědělstvi”, Prague, Wolters Kluwer ČR, a. s., 153 p. ISBN 978-80-7357-961-6. (In Czech).

[9] Explanatory memorandum of the proposal for a Council Directive amending Directive 2011/96/EU on the common system of taxation applicable in the case of parent companies and subsidiaries of different Member States (2011) [Online]. Available: lex.europa.eu/search.html?qid=1540913362410\&text=explanatory\%20memorandum\&scope $=$ EURLEX\&type $=$ quick\&lang $=$ en [Accessed: 16.07.2018].

[10] Fil'arská, J. (2017) “Prosperita pol’nohospodárskej prvovýroby vybraných spoločností podnikajúcich v oblasti ekologického pol'nohospodárstva na Slovensku”, Scientific Papers of the University of Pardubice - Series D, Faculty of Economics and Administration, Vol. XXIV, No. 39, pp. 16-27. ISSN 1211-555X. (In Slovak).

[11] Gyurián, N. and Kútna, A. (2015) "Direct taxes in Slovakia and their impact on economy of companies operating in agriculture and food producing industry", Studia Mundi - Economica, Vol. 2, No. 1, pp. 21-29. ISSN 2415-9395.

[12] Hanová, M., Benda Prokeinová, R., Hallová, M. and Čierna, Z. (2015) “Economic position of the Slovak inhabitant in Europe", ICABR 2015, Brno, Mendel University, pp. 273-282. ISBN 978-80-7509-379-0.

[13] Hornungová, J. and Milichovský, F. (2016) "Financial performance evaluation of the Czech agricultural companies with factor analysis", Scientific Papers of the University of Pardubice - Series D, Faculty of Economics and Administration, Vol. XXIII, No. 37, pp. 26-38. ISSN 1211-555X.

[14] Košovská, I. and Váryová, I. (2015) "Financial statements in small accounting entities", Journal of East European science and research, Vol. 6, No. 1, pp. 223-232. ISSN 1338-3302.

[15] Král'ovič, J. and Vlachynský, K. (2002) "Finančný manažment", Bratislava, Iura Edition, 415 p., ISBN 8089047173. (In Slovak)

[16] Martini J. T., Niemann, R. and Simons, D. (2012) “Transfer Pricing or Formula Apportionment? Tax-Induced Distortions of Multinationals' Investment and Production Decisions“, Contemporary Accounting Research, Vol. 29, No. 4, pp. 1060-1086. DOI 10.1111/j.1911-3846.2012.01140.x.

[17] Matuszewska-Pierzynka, A. (2015) "Net Profit Distribution Policy in Companies Using Stateowned Enterprises against Payment", Oeconomia Copernicana, Vol. 6, No. 2, pp. 89-107. E-ISSN 2353-1827. DOI 10.12775/OeC.2015.014.

[18] Mei, X. and Wei, X. (2015) "Analysis of dividend policy of listed company and its financial impacts", Proceedings of the 2015 International Symposium on Computers \& Informatics, Beijing, Peoples R China, Vol. 13, pp. 110-116. ISSN 2352-538X.

[19] Munk, M. (2011) “Počitačová analýza dát”, Nitra, UKF, 361 p., ISBN 978-80-8094-895-5. (In Slovak).

[20] Report on agriculture and food sector in the Slovak Republic 2009 (2010) [Online]. Available: http:/www.mpsr.sk/index.php?navID=122\&id=4162 [Accessed: ISBN 978-80-89088-95-9.

[21] Report on agriculture and food sector in the Slovak Republic 2010. (2011) [Online]. Available: http://www.mpsr.sk/index.php?navID $=122 \& \mathrm{id}=5214$ ISBN 978-80-8058-573-0.

[22] Report on agriculture and food sector in the Slovak Republic 2013. (2014) [Online]. Available: http://www.mpsr.sk/index.php?navID=122\&id=8835 [Accessed 14.07.2018]. ISBN 978-80-8058-597-6. 
[23] Sander, P., Kariler, J. and Viikmaa, K. (2014) "Determinants of Dividend Policy in Estonian Firms: An empirical analysis", International Multidisciplinary Scientific Conferences on Social Sciences and Arts (SGEM 2014), Albena, Bulgaria, pp. 193-199. ISSN 2367-5659.

[24] Saxunová, D. (2014) "Financial Statements under the US GAAP and IFRS: Theory, concepts, problems of financial accounting”, Prague, Wolters Kluwer, 192 p. ISBN 978-80-7478-646-4.

[25] Serenčéš, P., Tóth, M., Čierna, Z., Rábek, T. and Prevužňáková, J. (2014) "Benchmarking pomerových ukazovatelov finančnej analýzy v slovenskom polnohospodárstve“, Nitra, SPU, 155 p. ISBN 978-80-552-1159-6. (In Slovak).

[26] Sivák, R., Belanová, K. and Jančovičová Bognárová, K. (2015) “Financie podnikatelskej sféry", Bratislava, SPRINT 2 s.r.o., 344 p. ISBN 9788089710164. (In Slovak).

[27] Široký, J. and Valentová, I. (2013) "Evaluation of the Systems of Internal Double Taxation in the EU Countries from the Perspective of Corporate Shareholders", Proceedings of the $18^{\text {th }}$ International Conference: Theoretical and Practical Aspects of Public Finance, Prague, Univ Econ, Fac Finance \& Account, Dept Publ Finance, pp. 209-219. ISBN 978-80-245-2155-8.

[28] Šteker, K. and Otrusinová, M. (2013) “Jak čist účetní výkazy. Základy českého účetnictví a výkaznictvi”, Prague, Grada Publishing, a. s., 264 p. ISBN 978-80-247-4702-6. (In Czech)

[29] Taxation Trends in the European Union. (2018) [Online]. Available: https://ec.europa.eu/taxation customs/sites/taxation/files/taxation_trends_2018_country_chapter_hungary.pdf.[Accesse $\bar{d}$ 16.07.2018]. ISSN 2467-0073. DOI 10.2778/025314.

[30] Toder, E. and Viard, A. D. (2016) "Replacing corporate tax revenues with a mark-to-market tax on shareholder income", National Tax Journal, Vol. 69, No. 3, pp. 701-732. DOI 10.17310/ntj.2016.3.08.

[31] Tóth, M., Lančarič, D., Piterková, A. and Savov, R. (2014) "Systematic Risk in Agriculture: A case of Slovakia", AGRIS on-line Papers in Economics and Informatics, Vol. 6, No. 4, pp. 185-193. ISSN 1804-1930.

[32] Tóth, M., Matveev, V. and Boháčiková, A. (2016) "Risk of agricultural production in Russian Orel region", Potravinárstvo, Vol. 10, No. 1, pp. 557-562. ISSN 1337-0960. DOI 10.5219/664.

[33] Tumpach, M., Manová, E. and Meluchová, J. (2014) "Relevantnost' národného podnikového finančného výkazníctva $\mathrm{v}$ Slovenskej republike z pohl'adu veritel'ov ako neprivilegovaných používatel'ov", Ekonomický časopis: časopis pre ekonomickú teóriu, hospodársku politiku, spoločensko-ekonomické prognózovanie = Journal for economic theory, economic policy, social and economic forecasting, Vol. 62, No. 5, pp. 495-507. ISSN 0013-3035. (In Slovak). 